\title{
FORMATION OF INTEGRATED REPORTING IN THE CONTEXT OF SUSTAINABLE DEVELOPMENT
}

\author{
Olha Luhova', Tetiana Pisochenko²
}

\begin{abstract}
The purpose of the paper is to theoretically justify the preparation of integrated reporting, the influence of sustainable development ideas on the formation of the concept of integrated reporting, the problems of its creation and implementation in the practice of organizations. Methodology. The methodological and theoretical basis of the study was made up of the works of scientists and specialists in corporate reporting and sustainable development; frameworks, instructive and methodological materials for the formation of integrated reporting. We used general scientific methods of cognition such as comparison, analysis and synthesis, generalization, systematization, historical and logical methods. Results. Information deficiency arising from the formation of exclusively financial statements stimulates the emergence of integrated reporting. Non-financial reporting (social, environmental, etc.) provides useful information but does not reflect the relationship between different aspects of the company's activities and its results, which does not contribute to understanding its ability to create value over time. The constant trend of companies to sustainable development involves the study of issues of formation of integrated reporting as a tool for building a sustainable business. The integrated report aims to provide an insight into the company's resources and relationships that are known as the capitals and how the company interacts with the external environment and the capitals to create value. Key indicators of sustainability reporting, which should be reflected in integrated reporting, are grouped into three components: economic, environmental, and social. They are based on an assessment of the value of business and the value of capitals. Companies interested in implementing integrated reporting face a number of challenges, beginning with the fact that no globally accepted framework specifying what goes into an integrated report exists. But there are a growing number of examples of integrated reports from which companies can learn. Practical implications. This is an explanatory research to come with conceptual paper cited with recent literature for understanding the impact of sustainable development ideas on the emergence of integrated reporting. Despite the long list of internal and external challenges, the list of drivers contains a wide range of business advantages. Value/originality. Integrated reporting is a powerful tool for transparency and information openness of the company, which contributes to the sustainability of the business. Integrated reporting can become a tool for building a sustainable business for a company. In the process of its implementation and formation, the issues of the need to transform the company's management system, strengthen control over the solution of environmental and social problems, study and improve the company's business strategy should be resolved.
\end{abstract}

Key words: Integrated reporting, sustainable development, International Integrated Reporting Council, stakeholders, value creation, financial statements.

JEL Classification: M41, F20, F38, F63

\section{Introduction}

The 21 st century has been marked by the onset of the era of an innovative economy, in which the competitiveness of organizations and the state is inextricably linked with the introduction of the

\footnotetext{
Corresponding author:

${ }^{1}$ Mykolaiv National Agrarian University, Ukraine.

E-mail: olha-luhova@ukr.net

ORCID: https://orcid.org/0000-0003-4432-0295

ResearcherID: D-2389-2018

${ }^{2}$ Mykolaiv National Agrarian University, Ukraine.

E-mail: pisochenko@mnau.edu.ua

ORCID: https://orcid.org/0000-0001-5647-8167

ResearcherID: D-3590-2018
}

scientific and technological achievements into the economic process.

The great theoretical physicist Albert Einstein noted about technologies following: "It has become appallingly obvious that our technology has exceeded 
our humanity". Don DeLillo, American novelist, has the following point of view about technology: "This is the whole point of technology. It creates an appetite for immortality on the one hand. It threatens universal extinction on the other. Technology is lust removed from nature". Omar N. Bradley, an American military leader and general of the US Army, said the following: "If we continue to develop our technology without wisdom or prudence, our servant may prove to be our executioner". Three completely different personalities agreed on the same opinion - the development of technology can both improve our life and destroy it. Already, a detrimental effect of mass creation of various technologies is reflected in such global problems as increased pollution, severe depletion of natural resources, an increase in the proportion of the unemployed population replaced by artificial intelligence, and other important problems. Undoubtedly, all this cannot be ignored and requires the adoption of appropriate measures to neutralize the negative impact and ensure sustainable development.

Sustainable development is not only about achieving long-term profitability, but also about the company's acceptance of social and environmental responsibility. Long-term sustainability creates the necessary conditions for achieving the main business goal - value creation. Increasing the transparency and sustainability of the business requires the modernization of the company's reporting system. Traditional annual reports are unable to provide investors with enough relevant information to forecast the ability of corporations to create value in the long term. The economic environment changed dramatically in the last 20 years. Accounting needs to change accordingly.

It can be argued that accounting should be adapted to the changing conditions of a modern enterprise and more fully take into account aspects of sustainable development and strategic planning of economic consequences.

One of the most promising areas for the development of corporate reporting is the concept of integrated reporting, which accumulates current trends in the external environment and the needs of business partners. The concept is aimed at disclosing information about the creation of the company's value, reflecting the relationship between the results of the organization's activities and their various consequences, focused on the future, structured in accordance with the strategic objectives of the company and its business model.

Victor Hugo said that, "nothing is as powerful as an idea whose time has come". In a world of rapid change, the time has come to evolve our corporate reporting model. The time has come for integrated reporting.

Building Momentum: IIRC Integrated Report (2018) emphasizes that integrated reporting is viewed by many as the next evolution in corporate reporting, an antidote to the narrow and siloed focus on short-term, financial profit of traditional annual reports which is now accepted to have far-reaching destructive consequences for the environment, society and the economy.

Research in the field of integrated reporting is increasing and attracting a growing number of scientists: the relationship between integrated reporting and sustainable business development is the subject of works by R.G. Eccles and M.P. Krzus (Eccles, 2010), Dragu Ioana and Tiron-Tudor Adriana (Dragu, 2014), D. Tweedie and N. Martinov-Bennie (Tweedie, 2015). However, a deeper and more systematic understanding of the impact of sustainable development ideas on the emergence of integrated reporting is still required.

Consequently, the problem under study requires more attention in the following areas:

- the genesis of integrated reporting since the emergence of socially responsible business and solving environmental and social problems;

- the impact of sustainable development ideas on the formation of the concept of integrated reporting.

The aim of the paper is to study the issues of the genesis of integrated reporting with the determination of its place and role in the information support system of an enterprise in the context of sustainable development.

\section{The advance of Integrated Reporting}

In our opinion, the introduction of integrated reporting in business practice and its theoretical understanding is impossible without an analysis of its genesis.

Understanding that the true value of business is measured not only by the economic benefits that it brings to owners, but also its usefulness to society, led to increased interest in the concept of sustainable development and implementation of the principles of social responsibility, which, in turn, required adequate indicators and forms of their presentation. For this purpose, a set of standards and recommendations was developed to promote the implementation of the principles of socially responsible business conduct in management practice and to inform about it.

In 2015, world leaders agreed to 17 Global Goals (officially known as the Sustainable Development Goals or SDGs). These goals have the power to create a better world by 2030 , by ending poverty, fighting inequality and addressing the urgency of climate change. The 17 SDGs are integrated - that is, they recognize that action in one area will affect outcomes in others, and that development must balance social, economic and environmental sustainability.

Representatives of the audit company Deloitte (Deloitte, 2011) note: "Today, there are growing expectations that business do more than simply turn a profit. They must operate (and be perceived to operate) in a manner that is responsible, ethical, and 
sustainable; that minimizes negative impacts on the environment; that takes into consideration the varied needs of a spectrum of stakeholders; and that positively contributes to the communities in which they operate and the planet generally".

In our opinion, in relation to business, sustainable development is aimed at achieving long-term profitability, as well as taking on environmental and social responsibility. The Global Reporting Initiative (GRI) claims that more and more companies are striving to make their operations sustainable. GRI stresses that long-term profitability must be combined with social justice and environmental protection.

Information deficiency arising from the formation of exclusively financial statements stimulates the emergence of integrated reporting. Critics of the financial statements attribute the lack of forwardlooking data and non-financial information to its weaknesses. However, this information is in demand for the purpose of a comprehensive assessment of the firm's business, its competitiveness and investment attractiveness. The development of modern standards, recommendations and guidelines on the formation of reporting of a fundamentally new format is aimed at eliminating the shortcomings of financial information. The management of global processes, the description of the business environment and the business model of the company replace the process of regulating certain facts of the financial and economic activities of the company.

We can distinguish two major stages in the development of non-financial reporting for the period of its existence (over 25 years): "mono-reports" (environmental and social) and complex reports ("on the triple bottom line"). These reporting formats have significantly increased the scope of the information provided on the activities of companies. However, they turned out to be insufficient for the purpose of assessing the company's ability to create value. Currently, we can state the beginning of a new stage, a distinctive feature of which is the development of the concept of integrated reporting, which solves the problem.

It can be argued that the adoption of environmental and social responsibility by companies has contributed to the formation of ideas for sustainable development, which in turn are the forerunners of the development of the concept of integrated reporting. Thus, the one becomes an objective requirement of the time in conditions when:

- financial statements do not meet the growing information needs of users;

- business is becoming socially oriented and additionally assumes social and environmental responsibilities;

- companies, as well as the countries, tend to their sustainable development and appreciate not only the current achievements, but also focus on the future;
- non-financial reporting (social, environmental, etc.) provides useful information, but does not reflect the relationship between different aspects of the company's activities and its results, which does not contribute to understanding its ability to create value over time;

- there is a need for a comprehensive assessment of the organization and its capabilities, which requires disclosure of the higher-order information.

The highlighted factors are not exhaustive. However, in our opinion, they contributed to the development of the concept of integrated reporting as a new form of corporate reporting with financial and non-financial indicators.

The tendency to change the profession of an accountant and its role under the influence of the challenges of economic reality was revealed at the 19th World Congress of Accountants "2020 Vision: Learning from the Past, Building the Future" (IFAC, 2014). ACCA and IMA in their joint research "From Share Value to Shared Value" (ACCA/IMA, 2016) determined that the accounting profession has played a crucial role in pushing the idea of integrated reporting forward. The change in the focus of research on the International Integrated Reporting (IR) Framework in the direction of building a sustainable business for the company is of particular relevance. The constant tendency of companies to their sustainable development involves the study of issues of formation of integrated reporting as a tool for building a sustainable business. Many authors come to similar conclusions. Dragu Ioana and Tiron-Tudor Adriana (Dragu, 2014) define integrated reporting as the integration of information on sustainable development and corporate social responsibility in the annual report. Robert G. Eccles and Michael Krzus (Eccles, 2010) in their book "One Report: Integrated Reporting for a Sustainable Strategy" advocate the view that one report should be generated as a result of more integrated reporting, which will only be so if sustainability is incorporated into company strategy.

We share the statement of CLG member (GRI, 2017)

"We believe that integrated reporting is the way of the future; it is not possible to assess the health of the company solely with financial indicators".

An important part of the global push towards sustainability practices involves a need to account for, and report on, sustainability - sometimes referred to as environmental, social, and governance (ESG) reporting.

The existing state regulators cope with traditional forms of reporting with great difficulty; they have a very pragmatic function to ensure the receipt of tax and other fees and control of registers of basic property rights. In this context, the development of non-financial reporting has been the subject of study by predominantly non-governmental stakeholders (Table 1). 
Table 1

Organizations involved in sustainability and integrated reporting

\begin{tabular}{|l|l|}
\hline \multicolumn{1}{|c|}{ Organization } & \multicolumn{1}{c|}{ Mission } \\
\hline $\begin{array}{l}\text { International Integrated } \\
\text { Reporting Council (IIRC) }\end{array}$ & $\begin{array}{l}\text { aims to create a globally accepted framework for a process that results in communications by an organization } \\
\text { about value creation over time. }\end{array}$ \\
\hline $\begin{array}{l}\text { Global Reporting } \\
\text { Initiative (GRI) }\end{array}$ & $\begin{array}{l}\text { promotes the use of sustainability reporting as a way for organizations to become more sustainable and } \\
\text { contribute to a sustainable global economy. GRI's mission is to make sustainability reporting standard practice. }\end{array}$ \\
\hline $\begin{array}{l}\text { Climate Disclosure } \\
\text { Standards Board (CDSB) }\end{array}$ & $\begin{array}{l}\text { seeks to promote and advance climate change-related disclosure in mainstream reports through the } \\
\text { development of a global framework for corporate reporting on climate change }\end{array}$ \\
\hline $\begin{array}{l}\text { United Nations Environ- } \\
\text { ment Programme Finance } \\
\text { Initiative (UNEP FI) }\end{array}$ & $\begin{array}{l}\text { identifies the roles of the finance sector in addressing climate change, and advances the integration of climate } \\
\text { change factors - both risks and opportunities - into financial decision-making. This is done through a work } \\
\text { programme encompassing research, training, events and regional activities. }\end{array}$ \\
\hline $\begin{array}{l}\text { Deloitte sustainability and } \\
\text { climate change resources }\end{array}$ & $\begin{array}{l}\text { Deloitte, in collaboration with the Institute of Chartered Accountants in England and Wales (ICAEW), offers } \\
\text { a dedicated climate change website and video learning programme. The joint initiative is designed to help } \\
\text { businesses and finance professionals learn more about tackling climate change. }\end{array}$ \\
\hline
\end{tabular}

Source: prepared by the authors using (IAS Plus. Sustainability reporting and integrated reporting)

However, sustainability reports are still often produced in a silo alongside other reports such as financial statements. While individual reports still provide critical information to stakeholders, in isolation they are not sufficient to gain a comprehensive understanding of the full impacts and performance of a company. The establishment of the International Integrated Reporting Council (IIRC), of which GRI was a founding member, had the objective to help organizations provide a more comprehensive picture of how they are performing to create value over time across all relevant capitals.

Integrated reporting, which is founded on integrated thinking within the business, explains the interrelationships between financial and other capitals that the business depends on. The integrated report may link to more in-depth financial or sustainability information that different stakeholders require. A growing number of companies are already adopting this approach and are experimenting with ways to successfully implement this cycle of integrated thinking and reporting, enabling them to embed sustainability issues into their business strategy and communicate about it.

Bastian Buck (Director, Reporting Standards) (GRI, 2017) claims: "GRI believes that sustainability reporting experience is a necessary prerequisite for good integrated reporting. Integrated reporting does not replace the strategic element of the sustainability reporting exercise".

Differently from other forms of reporting, it is not an additional but rather an overall and holistic component of the system. Integrated reporting is intended to connect and bring together all the different components of the Corporate Reporting.

The IFRS Foundation and the IIRC both strive to progress the quality, consistency and accountability of corporate reporting through collaborative means. This collaborative effort was highlighted in 2020, as five global sustainability and integrated reporting organizations (CDP, CDSB, GRI, IIRC and SASB) published their statement of intent to work together, the IIRC and SASB announced their intention to merge, becoming the Value Reporting Foundation and the IFRS Foundation began an exploration into broadening its remit beyond financial reporting standards. Following a consultation on the creation of a Sustainability Standards Board, the IFRS Foundation has acknowledged the urgent demand for global consistency and comparability in sustainability disclosure. The IIRC supports this direction and believes that existing frameworks and standards, together with TCFD's recommendations, should act as the building blocks for the IFRS to develop global sustainability standards relevant to enterprise value creation.

The integrated report aims to provide an insight into the company's resources and relationships that are known as the capitals and how the company interacts with the external environment and the capitals to create value.

Value is not created by or within an organization alone. Organizations interact with their external environment and various capitals to create value over the short, medium and long term. That value has two interrelated aspects - value created for:

- The organization itself, which enables financial returns to the providers of financial capital

- Other stakeholders. An organization can think about value creation in terms of value to shareholders and funders, customers, employees, suppliers, partners, regulators and society.

Both aspects of value creation are critical to the survival of any organization - it cannot survive for very long delivering one without the other. Unless an organization creates value for itself it will risk going out of business; and unless it creates value for others it could either become irrelevant or lose its social licence to operate. 
The actions of stakeholders in the process of financial and economic activities should be based on the ideas of building a sustainable business, as well as on the principles of social and environmental responsibility. Stakeholders provide the company with the resources that form its capital. As a result of the commercial activity of the organization, the value of its capital increases, decreases or is transformed. As a result, value is created for the company and its stakeholders. The goal of the firm is to maximize its value by developing effective cooperation with stakeholders and optimal allocation of resources. The result of this approach is an integrated report as a tool for sustainable business development.

Integrated reporting is the way to achieve a more coherent corporate reporting system, fulfilling a need for a single report that provides a fuller picture of organizations' ability to create value. Integrated reporting can be used as an "umbrella" report for an organization's broad suite of reports and communications, enabling greater interconnectedness between different reports. The International Federation of Accountants (IFAC, 2017) also strongly supports the International Integrated Reporting Council and the implementation of its Framework.

IFAC has stated integrated reporting is the future of corporate reporting. Since its release in 2013, 1,700 companies in 72 countries have adopted the IIRC's $<$ IR $>$ Framework.

Chartered Accountants Australia and New Zealand (CA ANZ, 2019) believe that integrated reporting will be the reporting norm in most jurisdictions by 2022 if the International Integrated Reporting Council (IIRC) achieves its goals. As the demand for clearer communication grows, integrated reporting can help organizations meet their reporting obligations and tell their value story to investors and other stakeholders in a more compelling way.

\section{Indicators of integrated report}

As the IIRC Framework does not yet include a set of integrated reporting indicators, it is advisable to use both the indicators proposed by IFRS (and national accounting standards) and sustainable development indicators, as well as to use their own indicators of capital efficiency and indicators, which take into account the specifics of the company. Integrated reporting in terms of financial indicators should be based on three main concepts:

1) the concept of fair value, which allows users to provide information about the financial condition and results of the company, based on the real value of the reporting elements;

2) the substance over form concept, according to which professional judgment allows to draw conclusions about the economic form and more accurately reflect the elements of financial statements;

3) the concept of transparency, which provides a reflection of all the essential details of the company.

These three areas provide an opportunity to most accurately and comprehensively approach the assessment of the real state of the company's business. Integrated reporting should give an idea of the contribution that the company makes or intends to make in the future to improve or degrade the economic, environmental and social situation, development processes and trends at the local, regional and global levels.

Key indicators of sustainable development, which should be reflected in integrated reporting, can be grouped into three components:

1) economic component, which includes created and distributed economic value, revenues, operating costs, employee benefits, payments to suppliers, taxes, grants and investments, retained earnings;

2) environmental component, which includes the results of activities related to both input flows (raw materials, energy, water) and output flows (emissions, discharges, waste, as well as costs associated with the environment);

3) social component: the number of employees and staff turnover, the relationship between employees and management, health and safety in the workplace, training and education, wages and social benefits, investment in social projects.

The system of indicators of integrated reporting is shown in Figure 1.

Common to the indicators is that they are based on an assessment of the value of business and the value of capitals.

Meaningful disclosure of performance is essential to enable a critical assessment - internally by the governing body and management and externally by stakeholders. KPIs (and other quantitative indicators) compare and track performance against past and current targets and determine future targets. Ideally, KPIs are consistent year-on-year and any changes are explained.

The following Table 2 is helpful to organizations setting KPIs for the first time or where previously only financial KPIs had been set.

The information that must be provided in the integrated reporting requires certain tools, changes the approach to planning work on the preparation of integrated reporting and, accordingly, there is a need to solve the following tasks:

- making adjustments to all elements of accounting systems: methodology, techniques, organization of the accounting process, procedures for collecting and processing accounting information. It is necessary to develop internal regulations that determine what information is subject to disclosure. It is necessary to make changes in the structure of analytical accounts 


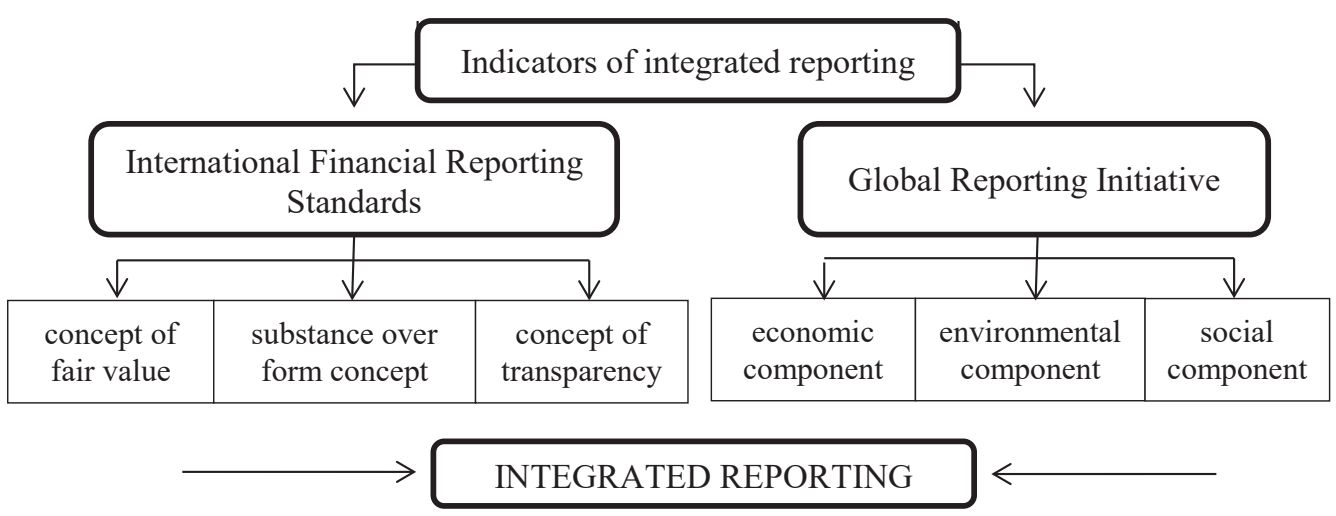

Figure 1. Groups of integrated reporting indicators

Source: formed by the authors

Table 2

Directions for setting KPIs in integrated report

\begin{tabular}{|c|c|}
\hline Directions & Setting of KPIs \\
\hline The organization's strategies and priorities & $\begin{array}{l}\text { When setting KPIs to measure actual performance against strategic targets consider the } \\
\text { organization's strategies and priorities: } \\
\text { - What are they? } \\
\text { - How do the governing body and executive team measure and monitor them? } \\
\text { - Are they reflected in remuneration packages, including the chief executive officer? Is there an } \\
\text { indication of how the leadership has performed against the strategies and priorities? }\end{array}$ \\
\hline What information is required internally? & $\begin{array}{l}\text { New reporters should consider the minimum information that will be required. It is easier to } \\
\text { start small than to immediately aim to be the best in the industry. } \\
\text { Consider the following questions when deciding what information to include: } \\
\text { - What information do senior management and executives require to make effective business } \\
\text { decisions? } \\
\text { - What information is needed to monitor achievement of strategies and priorities? } \\
\text { - Benchmarking - what are peers doing (industry, geographic, etc.)? } \\
\text { - What is the current best practice, for example King IV, GRI, etc.? }\end{array}$ \\
\hline What information is required externally? & $\begin{array}{l}\text { When considering the needs of users, ask the following questions: } \\
\text { - What information have stakeholders requested that are material to the organization? } \\
\text { - What are the relevant regulatory requirements, including laws, regulations, governance } \\
\text { standards etc.? } \\
\text { - What is the industry-specific information (for example, water usage and carbon emissions) } \\
\text { that applies to all organizations in the industry? } \\
\text { - What is important geographically (the information that is required when operating in a } \\
\text { geographic jurisdiction)? }\end{array}$ \\
\hline What information is currently available? & $\begin{array}{l}\text { Consider existing information: } \\
\text { - What financial and non-financial information is available? } \\
\text { - What is the information used for and how often is it compiled (monthly reporting/incentive } \\
\text { schemes/regulatory requirements etc.)? } \\
\text { - What information has historically been provided in reports? } \\
\text { - Is the available information internal or external and is it reliable? }\end{array}$ \\
\hline $\begin{array}{l}\text { Prioritise based on an information gap } \\
\text { analysis }\end{array}$ & $\begin{array}{l}\text { Once a gap analysis using existing information establishes what is required, the organization } \\
\text { decides on how quickly it can bridge the gaps - the most critical KPIs/information are } \\
\text { addressed first. The priority can be informed by the capitals and the material matters identified } \\
\text { for inclusion in the integrated report. } \\
\text { Embedding proper processes to ensure quality information takes time (even a number of years) } \\
\text { - focus on quality over quantity of information. }\end{array}$ \\
\hline
\end{tabular}

Source: formed by the authors 
in financial and management accounting, which will form the necessary for inclusion in the integrated reporting financial and non-financial analytical information;

- actualization of information systems of the entity;

- coordination of the activities of functional units that will be involved in the process of compiling and presentation integrated reporting;

- planning the process of preparing integrated reporting; - development of integrated thinking for compiling an integrated report;

-implementation of the principles of social responsibility in the practice of economic entity management in accordance with the ISO 26000 "Social Responsibility Guidance”, developed by the International Organization for Standardization, the UN Global Compact, etc.

\section{Criticism and challenges of integrated reporting}

Integrated reporting has not only advantages but also disadvantages that lead to significant difficulties in the transition from traditional financial to integrated reporting. Of course, as in all other fields, there are critics Solomon J. and Maroun W. (Solomon, 2012), Milne M.J. and Gray R. (Milne, 2013), Brown J. and Dillard J. (Brown, 2014), Flower J. (Flower, 2015) who focus their research skills on refuting the proven positive impacts of IR. Hence, they argue that there is still insufficient evidence to support that the International <IR $>$ Framework implementation influences organizational change in reporting and that, compared to previous guidelines (e.g. GRI), the IIRC Framework concept is highly regressive, i.e., that it has a limited and one-sided approach to assessment and reporting on sustainable issues.

Of course, integrated reporting is not a panacea for improving resource allocation decisions or a silver bullet for solving contemporary problems with financial and nonfinancial reporting, particularly as it is so young. Companies interested in implementing integrated reporting face a number of challenges, beginning with the fact that no globally accepted framework specifying what goes into an integrated report exists. But there are a growing number of examples of integrated reports from which companies can learn.

A closely related problem is that there is no globally accepted set of standards for measuring and reporting nonfinancial information. Few companies have internal control and measurement systems for nonfinancial information that are of the same quality as for financial information. Simply gathering all the nonfinancial and financial information to issue an integrated report is a formidable challenge in most companies.

Editors of the Journal of Accounting \& Organizational Change, 2021 state that how organizations change is also reflected in how organizations adopt the integrated reporting because not all organizations adopt all elements of the framework. For example, some organizations rely only on integrated reporting's principles, while others analyse and measure all six capitals and their transformation through their business model. Some organizations also explain their governance and strategy, and their business model, and identify their tangible and intangible assets and present the key risks they face and how they plan to avoid or mitigate them. To other organizations, integrated reporting can appear "complex and timeconsuming" because the structuring of non-financial information is not as advanced as that of financial information, or is "costly" to produce. Thus, different organizations implement integrated reporting differently, making it hard de facto to compare one integrated report to another.

Forward-looking information is central in integrated reporting, as one of its most innovative features is the orientation to the future. If this kind of information is extremely relevant to investors, at the same time, it may damage the corporation because competitors may have access to proprietary information.

Generalized disadvantages and challenges of the integrated reporting are as follows:

- the need to balance professional, administrative, regulatory requirements in the preparation of integrated reporting;

- the difficulty of summarizing the information interests of all groups of stakeholders in one report;

- the difficulty in determining key performance indicators;

- the time-consuming and costly process of transition from financial reporting to integrated;

- the underdevelopment of the sustainable development accounting system carries additional risks to ensure the reliability of integrated reporting;

- lack of uniform requirements for the preparation of integrated reporting;

- the need for high-level specialists to compile integrated reporting;

- the absence, stated as an advantage, of the possibility of comparing the information provided by different companies because of its incompatibility;

- preparation integrated reporting requires knowledge in many areas;

- the complexity of estimation non-financial assets;

- increasing the risk of disclosure of trade secrets;

- inaccuracy of forecast indicators.

Questions exist about the reliability of the information reported by companies. For the most part, having any type of third-party assurance on nonfinancial information in the report, let alone on the entire integrated report, is voluntary. And even when assurance is provided, it is not done with the same degree of rigor as the audit of a financial report. 
Table 3

Main external and internal drivers and challenges to integrated reporting

\begin{tabular}{|c|c|}
\hline Drivers & Challenges \\
\hline \multicolumn{2}{|c|}{ External } \\
\hline $\begin{array}{l}\text { - Framework is adapted to investors' language (capitals, value creation) } \\
\text { - Legislation on transparency and reporting } \\
\text { - High standards on accounting } \\
\text { - Policy measures } \\
\text { - Stock exchange listing } \\
\text { - Shareholder pressure/possibility to see how sustainability impacts } \\
\text { financial value and risks } \\
\text { - Information need of stakeholders on how a company creates value }\end{array}$ & $\begin{array}{l}\text { - Risk of enhanced disclosure - liability (e.g. on outlook) } \\
\text { - Risk of greenwashing } \\
\text { - Expectations on Assurance } \\
\text { - Stock listing (long term vs. short term)/ support by investors } \\
\text { not always evident } \\
\text { - Different guidelines for reporting (G4 - SASB IIRC- Form } \\
\text { 10-k and others) } \\
\text { - Lack of IR thinking at governmental level }\end{array}$ \\
\hline \multicolumn{2}{|c|}{ Internal } \\
\hline $\begin{array}{l}\text { - Easier access to financial capital } \\
\text { - Internal engagement (multidisciplinary, all levels) } \\
\text { - Integrated strategy linked to purpose } \\
\text { - Connect financial - CSR department/ breakdown silos } \\
\text { - Stimulates integrated thinking / Holistic approach } \\
\text { - Stimulates integrated risk management } \\
\text { - Support tenders } \\
\text { - Expected link with business performance } \\
\text { - Enhance stakeholder engagement } \\
\text { - Focus on material issues } \\
\text { - Focus on strategy and longer term value creation } \\
\text { - Better allocation of capital / resources } \\
\text { - Drives KPI setting on both financial and non-financial material aspects } \\
\text { - Favours monetization } \\
\text { - Report non-financial data more frequently }\end{array}$ & $\begin{array}{l}\text { - Conceptual framework, lacks practical application } \\
\text { - Collection, measurement and valuation of non-financial data } \\
\text { - Defining smart targets } \\
\text { - Full board commitment } \\
\text { - Embedding throughout the entire organization } \\
\text { - Conciseness of report versus completeness } \\
\text { - Industry-specific regulations might not favour IR } \\
\text { - Lack of evidence that IR links to business performance } \\
\text { - Consistency (connectivity) of materiality matrix, strategy, } \\
\text { targets, and performance }\end{array}$ \\
\hline
\end{tabular}

Source: formed by the authors using (Deloitte, 2015)

The following table provides an overview of the main external and internal drivers and challenges to integrated reporting.

Despite the long list of internal and external challenges, the list of drivers contains a wide range of business advantages. This would suggest that the uptake of IR would continue slowly but surely.

Although these challenges are significant, they can and must be overcome, and quickly. A sustainable society requires that all of its companies practice integrated reporting, so that resources used today do not jeopardize access to resources for future generations. There really is no alternative to integrated reporting. This still infant idea needs to grow into a strong and robust management practice. Doing this requires a cross-sector approach that involves the public and private sectors, and civil society as represented by NGOs.

\section{Conclusions}

Integrated reporting reflects a holistic picture of the company's development, which allows the company to gain the trust of stakeholders and develop relationships with them. The completeness of disclosure of financial and non-financial information allows investors to draw informed conclusions about the company, the main opportunities and risks.
It facilitates operational control and financial risk management. Integrated reporting makes it possible to collect and comprehensively analyse information regarding the company's performance, its sustainable development. Based on this information, decisions related to the company's future strategy, ways to minimize costs and risks are made.

The integrated report tells the organization's value creation story clearly and concisely. It gives a holistic view of the organization's current position, as well as its strategic goals and how it intends to reach them. Users should be able to assess how the organization creates positive and negative value over time, for itself, its stakeholders and the environment.

The integrated report should not be seen as yet another compliance burden. It is a good communication tool that also offers many internal benefits for the organization. Integrated reporting is a journey. It is unlikely that the organization will meet all objectives for its integrated report in the first year, but reporting will improve as the organization remains committed to the journey.

More analysis is needed on the firm characteristics and determinant variables in the implementation of integrated reporting, its quality and quality of management, and market reactions to such adoption. Additionally, how the display of intellectual capital and other forms of capital in integrated reporting 
contribute to the value creation in longer periods needs to be explored. Integrated reporting quality and e.g., accuracy of analysts' forecast and firm valuation are other emerging topics for future research.

Controlling variables such as ownership, corporate governance factors, age of the company, emerging information technologies may also be included to test how firm performance is reflected with the implementation of integrated reporting.

Furthermore, investor's opinions of the IR need also to be examined in details.

Last but not the least, it looks that the measurement of IR quality is also questionable. International $<\mathrm{IR}>$ Framework needs to be standardized IIRC needs to think of introducing a checklist for measuring IR quality.

Integrated reporting should contain all significant data on the company's strategy, corporate governance, performance indicators and prospects that reflect its economic, social and ecological environment. In addition, there must be a clear and concise understanding of how the company is managed and how it creates value.

The study found that the history of integrated reporting dates back to the advent of the International
$<$ IR $>$ Framework and the official publication of integrated reporting by individual companies, and its current structure was formed as a result of expanding information needs of users of accounting information.

Integrated reporting is a powerful tool for transparency and information openness of the company, which contributes to the sustainability of the business. Corporate transparency is a significant factor that ensures the growth of business value and is directly related to the formation of integrated reporting indicators that characterize the value created. In this regard, the need for the development of analytical support for integrated reporting in the context of sustainable business is currently increasing.

In our opinion, integrated reporting can become a tool for building a sustainable business for a company. In the process of its implementation and formation, the issues of the need to transform the company's management system, strengthen control over the solution of environmental and social problems, study and improve the company's business strategy should be resolved. This becomes necessary to meet the high demands placed on integrated reporting.

\section{References:}

Brown, J., \& Dillard, J. (2014). "Integrated reporting: on the need for broadening out and opening up". Accounting, Auditing \& Accountability Journal, vol. 27, no. 7, pp. 1120-1156. doi: 10.11089AAAJ-04-2013-1313

Chartered Accountants Australia and New Zealand (2019). How integrated reporting < IR $>$ tells the value story. Retrieved March 19, 2021, from https://www.acuitymag.com/finance/how-integrated-reporting-tells-the-valuestory

Deloitte (2011). Integrated reporting: A better view? Retrieved March 19, 2021, from https://www.iasplus.com/ en/binary/sustain/1109integratedreportingview.pdf

Deloitte. (2015). Integrated Reporting as a driver for Integrated Thinking? Retrieved March 22, 2021, from https://www2.deloitte.com/content/dam/Deloitte/nl/Documents/risk/deloitte-nl-risk-integrated-reporting-adriver-for-integrated-thinking.pdf

Dragu Ioana, \& Tiron-Tudor Adriana (2014). Research Agenda on Integrated Reporting: New Emergent Theory and Practice. Procedia Economics and Finance, vol. 15, pp. 221-227. doi: 10.1016/S2212-5671(14)00488-2

Eccles, Robert G., and Michael Krzus (2010). One Report: Integrated Reporting for a Sustainable Strategy. New York: John Wiley \& Sons.

Flower, J. (2015). “The international integrated reporting council: A story of failure”. Critical Perspectives on Accounting, vol. 27, pp. 1-17. doi: 10.1016/j.cpa.2014.07.002

GRI (2017). Forging a path to integrated reporting. Insights from the GRI corporate leadership group on integrated reporting. Retrieved March 19, 2021, from http://integratedreportingsa.org/ircsa/wp-content/ uploads/2017/05/GRI-CLG_IntegratedReporting.pdf

IAS Plus. Sustainability reporting and integrated reporting. Retrieved March 23, 2021, from https://www.iasplus.com/en/resources/sustainability/sustainability

Institute of Management Accountants (2016). From Share Value to Shared Value: Exploring the Role of Accountants in Developing Integrated Reporting in Practice. Retrieved March 19, 2021, from https://www.imanet.org/insights-and-trends/external-reporting-and-disclosure-management/share-value-toshared-value? ssopc $=1$

Integrated reporting and change?: The impacts after a decade of integrated reporting. Journal of Accounting \& Organizational Change, 2021. Retrieved March 19, 2021, from https://www.emeraldgrouppublishing.com/ journal/jaoc/integrated-reporting-and-change-impacts-after-a-decade-integrated-reporting

International Federation of Accountants (2014). Opening Remarks to World Congress of Accountants 2014. Retrieved March 19, 2021, from https://www.ifac.org/news-events/2014-11/opening-remarks-world-congressaccountants-2014 
International Federation of Accountants (2017). Enhancing Organizational Reporting: Integrated Reporting Key. Retrieved March 19, 2021, from https://www.ifac.org/knowledge-gateway/contributing-global-economy publications/enhancing-organizational-reporting-integrated-reporting-key

International Integrated Reporting Council (IIRC) (2018). Building Momentum: IIRC Integrated Report 2018. Retrieved March 19, 2021, from https://integratedreporting.org/integratedreport2018/download/pdf/IIRC_ INTEGRATED REPORT 2018.pdf

Milne, M. J., \& Gray, R. (2013). "W(h)ither ecology? The triple bottom line, the global reporting initiative, and corporate sustainability reporting", Journal of Business Ethics, vol. 118, no. 1, pp. 13-29. doi: 10.1007/s10551-0121543-8

Solomon, J., \& Maroun, W. (2012). "Integrated Reporting: The Influence of King III on Social, Ethical and Environmental Reporting", The Association of Chartered Certified Accountants, London.

Tweedie, D., \& Martinov-Bennie, N. (2015). "Entitlements and Time: Integrated Reporting's Double-edged Agenda". Social and Environmental Accountability Journal, vol. 35, iss. 1, pp. 49-61. doi: 10.1080/0969160X.2015.1007466 